\title{
Perspectives on Nature's Metropolis: A Book Forum
}

Nature's Metropolis: Chicago and the Great West, by William Cronon. New York: W. W. Norton, 1991. xxiii, 530 pp. Illustrations, maps, graphs, notes, appendix, bibliography, index. $\$ 27.50$ cloth.

\section{EDITOR'S INTRODUCTION}

When I received a review copy of William Cronon's book, Nature's Metropolis: Chicago and The Great West, last fall, I prepared to browse in it as I do in most books I receive for possible review in the pages of the Annals. Almost immediately, however, the book's argument and its details struck me with uncommon force. I found myself captivated by its richness and stimulated by its metaphors about the relationships between city and countryside and between first nature ("original, prehuman nature") and second nature ("the artificial nature that people erect atop first nature") (xvi). Most of all, as editor of The Annals of Iowa, I was intrigued by the book's implications for the history of Iowa and the Midwest. I became convinced, as I read, that a book of such significance comes along only about once every generation or so, especially for this region (seminal books appear more often in southern and even western history). To do my part to ensure that historians of Iowa not overlook this book as an "urban history" book about Chicago that would have little relevance for Iowa history, I decided to ask four historians to address the book's significance in the pages of the Annals.

THE ANNALS OF IOWA 51 (Summer 1992). CThe State Historical Society of Iowa, 1992. 
At the heart of Nature's Metropolis is an abstract irony with very practical consequences: the market systems developed in the nineteenth century bound city and country folk together in a pattern of consumption that allowed them to separate products from the means of production. By the close of the century, as Cronon says, "The Iowa farm family who raised corn for cattle purchased from Wyoming and who lived in a farmhouse made of Wisconsin pine clothed themselves with Mississippi cotton that Massachusetts factory workers had woven into fabric, worked their fields with a plow manufactured in Illinois from steel produced in Pennsylvania, and ended their Sunday meal by drinking Venezuelan coffee after enjoying an apple pie made on an Ohio stove from the fruit of a backyard orchard mixed with sugar from Cuba and cinnamon from Ceylon" (310). Such an array of products, so easy to take for granted, would have been unthinkable for an lowa farm family without the intricate web of market relations that came to link Chicago and the Great West in the last half of the nineteenth century. Nor could those products have been created without the transformations of nature that are as evident to Cronon in the plowed fields of Iowa and the second-growth forests of Wisconsin as they are in the congested streets and towering buildings of Chicago (3).

Nature's Metropolis addresses the concerns of historians with a wide array of interests. I asked each of the historians whose essays appear here to address the implications of discrete, if related, aspects of the book. The book has much to say about the transformation of the frontier, a topic I knew Malcolm Rohrbough could talk about with authority and grace. Cronon analyzes that transformation from an environmental perspective that all of the essayists agree is the book's most provocative aspect. Philip Scarpino, who has written an environmental history of the upper Mississippi River, is well equipped to discuss that aspect of the book. Sandwiched between the essays by Rohrbough and Scarpino are essays by an urban historian and a rural historian. Cronon insists that throughout his struggles to write the book, he "held fast to one central belief: city and country have a common history, so their stories are best told together" (xiv). Yet the history of the city and the country have developed as distinct subdisciplines, particularly in the 
past couple of decades. I thought it would be useful to see how representatives of each subdiscipline would react to the book. Timothy Mahoney's work on Mississippi River towns qualifies him to represent economic historians and historical geographers as well as urban historians, so I asked him to reflect on Cronon's geographical, market-oriented analyses of the relationship between Chicago and its hinterland. And I knew that David Danbom could offer a provocative assessment of the book's potential impact on rural historians.

I asked each contributor generally whether Cronon's book might change the way they or their colleagues think and write about the history of the Midwest, and if so, how. By refusing to define their assignments narrowly, I hoped to encourage each of them to offer a personal response to the book. They did not disappoint me. Each took a quite different tack. Malcolm Rohrbough gives a careful and cogent summary of the book's key points and then goes on to suggest three significant questions the book leaves open for students of the American frontier. Timothy Mahoney took advantage of his own knowledge of the workings of Chicago's hinterland to outline a framework for its history that he finds implicit in dispersed passages within Cronon's book. David Danbom highlights the challenge Cronon's environmental perspective raises for the way agricultural historians have approached their studies. Finally, Philip Scarpino assesses the book's place in a growing historical literature about the environment, and he also takes advantage of his position within a public history program to comment briefly on how public historians might make use of the book. William Cronon's creative and constructive response concludes the forum.

This forum provides an opportunity for historians to exchange ideas about the way this book affects how they see the past. Their number could have been multiplied, for the book has much to say to historians in other subdisciplines of American history, such as business history, the history of technology, and railroad history, to name a few. Cronon's book encourages such exchanges among historians, as Philip Scarpino points out in his essay. This forum offers all of us, even if we do not share these historians' specialized knowledge 
of the topics they discuss, a window through which we can see historical interpretations being defined and refined.

Yet I would be remiss if I didn't point out that Professor Cronon probably has justifiable cause to hope that his book will reach some general readers who are interested in the history of their region. The book, as a couple of the reviewers point out, is often abstract. Yet it is rich in metaphors and direct, practical applications of abstract insights. And it is so clearly written that after reading Cronon's explanation of the grain futures market (120-32), I felt, for the first time, that I actually understood how it worked. Similarly, in chapter two he offers the clearest discussion I can recall of the geographic and economic consequences of railroad development. His amazingly concise description of the concrete and symbolic consequences of the destruction of the bison herds on the Great Plains (215-18) is even more compelling. I commend the book to anyone interested in the general history of this region.

In the end, though, the goal of these essays is not to'celebrate Nature's Metropolis. (The awards it has earned, such as the Bancroft Prize, do that more adequately.) The most important history books are those that are challenged for a generation or more (Frederick Jackson Turner wrote an essay one hundred years ago that is still being challenged). This forum, then, seeks to call attention to the paths that this indisputably important book has charted. I hope these essays will suggest ways that others might follow its lead or challenge the directions it charts.

\section{MALCOLM J. ROHRBOUGH}

William Cronon's Nature's Metropolis: Chicago and the Great West is a magisterial study of the relationship between city and countryside over the last two generations of the nineteenth century. No review, however detailed and fluent, can fully encompass a range of enquiry that runs from railroads and boosters to grain futures and mail order houses. What I propose here is to set out the central directions of the book and then comment on the salient questions it poses about the study of the American frontier. Like the best historical literature, this volume invites 
comment and further enquiry. The intellectual fallout from its publication should spread across the field for years to come.

Cronon begins by introducing us to his idea of nature. By his own admission it is his "most problematic" term. He develops a basic distinction between first nature ("original, prehuman nature") and second nature ("the artificial nature that people erect atop first nature") (xvii). He makes repeated references to these differences as he details Chicago's growth in its first frantic generation of life.

Cronon divides his study of the interactions between first and second nature into three major parts. In the first he describes and analyzes Chicago's rise as a central city for the great outlying prairies. Its emergence was based simultaneously on the natural advantages of its site and on the unbounded energy and optimism of its boosters. Cronon's discussion of the booster mentality identifies that combination of the visionary and the practical that made Chicago the perfect subject for such ambitions. Chicago began its commercial life as a site of water commerce, but it was the arrival of the railroad that made it America's most dynamic city and bound it in a lasting but changing relationship to an ever-expanding countryside. The railroad's influence grew with the expansion of rail lines to the West and the movement of agricultural settlement in advance of them. "By 1860," Cronon writes, "eastern investors and Chicago railroad managers had succeeded in imposing a new geography on the western landscape" $(68)$. It was a geography in which all rail lines west of Lake Michigan led to the city.

Cronon's second section of some one hundred and fifty pages describes the transition from "nature" to market of three commodities so central to the rise of the Great West and its city: grain, lumber, and meat. Key institutions - the steam-powered grain elevator, the grading system, and the Board of Tradewere in place by the mid-1850s. The image of the conjunction of railroads, ships, and golden streams of wheat is a compelling one. And it is here that the author delivers what is perhaps the first clear account of the futures market ever to appear in historical literature (120-32). Cronon emphasizes that Chicago did nothing exotic or new; it simply did more of it. In this way it became "the site of a country fair, albeit the grandest, most spectacular country fair the world had ever seen" (97). 
Lumber had its own special dimensions. Like the tallgrass prairie that preceded the grain belt, so the great northern forests of first nature were sacrificed to human progress and profit. The endless expanse of white pine that loomed in the northern forest could be floated south on Lake Michigan to the mart of Chicago, where its sawed boards provided the materials lacking in the level treeless prairies so adaptable to agriculture. Chicago was the meeting place of these two needs. "Once again," notes Cronon, "the city benefited from the intersecting geographies of nature and capital," and it "emerged during the 1850 s as the single greatest lumber market in the world" (154, 169). But the white pine forest began to disappear, and the lines of commercial connection sought other sources. By the 1880 s, the railroads that had originally given Chicago preeminence in the lumber business now reached out to its competitors. New and distant pine forests came into play as the pine lands of Wisconsin, Michigan, and Minnesota vanished. As early as 1877, southern lumber appeared on the Chicago market. This initial blending of ecological and market forces ended with the destruction of the ecosystem of the northern forest, but by the turn of the century, Chicago, with an adequate lumber supply from across the nation, scarcely noticed (206).

The third great influence that Cronon discusses is the stockyards. With the ingredients of capital, transportation, and a high degree of structural organization, far-sighted entrepreneurs organized the nine railroads and several small pens into the Union Stockyards. Opened for business in 1865, this unified yard would eventually hold 2,300 separate pens on one hundred acres, with a capacity of 21,000 head of cattle, 75,000 hogs, 22,000 sheep, and 200 horses, all at the same time (210). "Simple in basic plan," writes Cronon, "the stockyard was a triumph of the engineer's craft" (211). Once again, the city (this time through the medium of the stockyard and the Exchange Building) served as the meeting point between countryside and city. The basic changes wrought by these institutions involved livestock dealers, meatpackers, grain farmers, stock raisers, butchers, and eventually changes in the American diet (212). Cronon analyzes the emergence of the livestock industry in the Great West between 1860 and 1890 as "another manifestation of second nature, noteworthy for its economic complexity and 
geographical extent" (223). Through technological innovations in transportation (the refrigeration car), techniques to process large numbers of animals with new efficiency, and ruthless marketing methods, Chicago packers had come to dominate much of America's meat supply by the late 1880 s (244). Their far-reaching influence touched the lives of ranchers in Wyoming and feedlot farm families in Iowa (254). After the turn of the century, Chicago gradually lost (or perhaps shared) its supremacy, as the large packing houses built plants in Omaha and Kansas City near the source of supply.

Cronon's third section, covering about one hundred pages, traces the flow of capital throughout Chicago's immense hinterland, an exercise that is necessary to understand the emergence of second nature with its single region, economy, and ecology (269). To map the secretive movement of capital, Cronon focuses on bankruptcy records. Maps of creditors in bankruptcy proceedings show the diversity of Chicago's hinterland. The analysis of bankruptcy records lets him establish a "western urban hierarchy as it had developed by the $1870 \mathrm{~s}$ " (284). With his maps (limited to the years 1873-1874) Cronon produces a careful analysis of bankruptcy, including an appendix on the methodology behind his bankruptcy maps (387-90). This intense focus on bankruptcy provides a useful literary counterpoint to the other large-scale themes that command the author's attention. In a massive study almost entirely without appealing human characters to capture our interest in this smoky and sterile landscape, the immediacy of the bankruptcy study captures our attention on several levels and provides a useful contrast in microcosm to this epic of great themes.

In this section, Cronon provides an excellent discussion of the small towns and villages that formed the retail outlets for Chicago's wholesale trade (279-82). He writes of this economic influence that by the end of the century, "from the Appalachians to the Sierra Nevada, the Great West was Chicago's domain" (282). He continues with the observation that "the hierarchy of city, town, and country that appeared so quickly in the Great West during the second half of the nineteenth century represented a new phase of American frontier expansion" (283). Chicago as "gateway city" was the intermediary between the towns and countryside of the Great West and 
the "maturing capitalist economy of the Northeast and Europe" (284). In the course of his discussion, Cronon offers an excellent analysis of local merchants such as John Burrows of Davenport and Charles Brewster of Fort Madison and the relationship of their world to Chicago after the expansion of the railroad. The railroad brought the city and the countryside together, accelerated transactions, increased the volume of capital, and changed the worlds of merchants such as Burrows and Brewster by subjecting them to a new kind of competition that they could not manage. A further step in concentrating retail transactions within Chicago's field of force was the introduction of the mail order store, whose extraordinary growth was testimony to its expansive influence. In 1872 Montgomery Wards' catalog contained 163 items with prices on a single eight-by-twelve sheet. By 1890 , Wards' catalog had 540 pages and listed 24,000 items offered to readers (336).

Cronon closes his book with an account of the great World's Columbian Exposition of 1893, when Chicago played host to the world. On the occasion of the celebrations of the four hundredth anniversary of the first Columbian voyage, Chicagoans would "suggest that their own city was itself the fulfillment of a destiny that Columbus had long ago set in motion" (341). The fair was only a symbol for the mixture of beauty and power that was Chicago itself. Cronon concludes by emphasizing once again that the stories of Chicago and the Great West must be told together.

Cronon's analysis of the growth and sovereignty of the city of Chicago suggests three questions that should concern historians of the American frontier. What is the relationship between the city and the country? What is the scope, significance, and meaning of the term the Great West? Does Cronon's study of Chicago represent a useful model for the study of the American frontier?

Cronon's analysis of the relationship between the city and its hinterland is compelling. Chicago is an extraordinary example of the power and presence that influences people, animals, and ecology a thousand miles to the West. The impact of the country on the city, as Cronon points out, is no less profound. The final evidence of this reciprocal condition is the decline of Chicago with changing circumstances. By the turn of the cen- 
tury, for example, the great pine forests of the north were gone, the railroads had brought southern lumber to the city, and the large meatpackers were laying plans to build plants in Omaha and Kansas City, closer to the source of supply. Cronon's hierarchy of cities also makes sense, for he has paid careful attention to the rise of smaller metropolitan centers that pay tribute to the colossus of Chicago.

Still, his dramatic story of the significance of Chicago is an epic that, in many ways, begins in the middle. His declaration that "the frontier history of the Great West looks to be a story of metropolitan expansion, of the growing incursions of a market economy into ever more distant landscapes and communities" (378) raises the question of how to mark the history of these same entrepreneurial and technical forces up to 1840 . Two generations earlier, at the close of the American Revolution, the combinations of commerce, government, and technology in the new Euroamerican settlements in Kentucky and Tennessee, joined soon thereafter by other scattered outposts in the Old Northwest, produced other kinds of frontier societies built around urban centers. These settlements, following early fur trading patterns, concentrated around small villages (or "stations"), which provided a wide range of support services and economic opportunities. Lexington (Kentucky), Marietta (Ohio), Shawneetown (Illinois), and Franklin (Missouri), to mention only four in different locations and different times, are examples of these early urban areas. ${ }^{1}$ The ingredients of merchants and boosters from town mixed with farmers and traders from the hinterland form the same combination in microcosm that later marks the astonishing rise of Chicago. Even though Chicago's rise dwarfs earlier and smaller examples, it surely contains the same influences and may even draw from their examples.

To move forward a generation, the astonishing spread of the steamboat after 1815 surely wrought other startling changes on urban life and urban relationships with the countryside. Indeed, the steamboat produced its own array of new

1. See the discussion in Malcolm J. Rohrbough, The Trans-Appalachian Frontier: People, Societies, and Institutions, 1775-1850 (New York, 1978), chap. 14, esp. 357-59. 
towns, all with ambitions to become cities and to capture the tribute of the surrounding hinterland. St. Louis and New Orleans are the best-known examples, but Terre Haute (Indiana), Peoria (Illinois), Blakeley (Alabama), and Apalachicola (Florida) are remarkable in their own ways. ${ }^{2}$ Each represented the powerful influence of the steamboat on the surrounding hinterland.

The second enquiry has to do with the term Great West and its usefulness in defining a unit of historical analysis. Here, too, Cronon's case is a powerful one. What we see developed in his Great West goes beyond anything historians have heretofore imagined. ${ }^{3}$ At its height, in the late nineteenth century, Chicago's Great West hinterland stretched from "Michigan and Ohio to Montana, Nevada, and New Mexico. All western cities served as markets for their hinterlands, but Chicago did so with greater reach and intensity than any other" (148). It was truly a magnificent kingdom, greater in area than many European principalities and certainly generating wealth that would have been the envy of royalty around the world.

Yet Cronon's Great West intrigues us by what it is not. Its geographic range really makes it the Great Northwest. South of the Ohio River lies the Great Southwest, dark with forests and slavery and white with rice and cotton. Cronon notes in passing the significance of New Orleans. The Crescent City commanded an empire almost as valuable as Chicago's, yet quite different. The stories of the Euroamerican frontier societies in the South in the three generations from the Peace of Paris to the firing on Fort Sumter produce three characteristics that contrast with Cronon's study of Chicago. First, southerners rapidly occupied (or seized from Native Americans) lands in distinct geographic blocks in response to Native American land cessions, especially in Georgia, Alabama, and Mississippi, as a direct reaction to the spread of cotton culture. Second, there was no single central market to fill the role Chicago played for the Great Northwest. Third, the widespread cultivation and marketing of bulk agricultural commodities to a world (Euro-

2. Ibid., 173, 176, 366-67, 252.

3. Compare, for example, the use of the term in R. Carlyle Buley, The Old Northwest: Pioneer Period, 1815-1840, 2 vols. (Indianapolis, 1951). 
pean and North American) market, including cotton, rice, and sugar, generated their own intense commercial life, which required special support services of the kinds provided by urban centers. Cronon's study of Chicago establishes a model against which to begin the study of the Great Southwest in the three generations before the Civil War.

Finally, we turn to the largest question, namely, whether Cronon's study represents a useful model for the study of the American frontier. The answer is clearly yes. This brief response does not do justice to the complexity of the issues that Cronon describes and analyzes or to the extraordinary range of his enquiries. What is especially significant is the scale of his enquiries, with respect to space and time. Other historians have produced significant studies on a small scale: ${ }^{4}$ But no one has heretofore succeeded in showing the complex interaction of city and countryside on such a large canvass. Cronon has found a striking relationship between Chicago and its hinterland, and he has found the connection to be far closer and more complex and the hinterland far greater than anyone has heretofore imagined. What we need now is to press the concept of the Great West and the central marketplace back another sixty years to the two generations after the Revolution, when Euroamerican settlers began to occupy the Ohio and Mississippi valleys in such great numbers. Perhaps we can find there the antecedents of Cronon's Chicago epic.

\section{TIMOTHY R. MAHONEY}

Between 1860 and 1890 , Chicago, perhaps unlike any other city before or since, stood "in the right place at the right time" (231). Situated halfway between the industrial East and the developing "Great West," Chicago was poised to bring together a series of revolutionary economic, technological, and organizational

4. See, for example, Merle Curti, The Making of an American Community: Trempeleau County, Wisconsin (Stanford, 1959); John Mack Faragher, Sugar Creek: Life on the Illinois Prairie (New Haven, 1987); and Don Harrison Doyle, The Social Order of a Frontier Community: Jacksonville, 1825-1875 (Urbana, 1978). 
innovations "that left few aspects of nineteenth-century life untouched" (92). The energy unleashed by this fortuitous intersecting of forces made Chicago the fastest-growing metropolis in the world and the archetypal city of the age. Explaining how and why these forces intersected at Chicago in the years just before and after the Civil War is the central economic and urban historical focus of William Cronon's Nature's Metropolis.

To many historians of Chicago, the Midwest, and urban America, Cronon's telling of the story may at first appear to be a particularly well-structured, well-written, and evocative account of a familiar series of events, but one that nonetheless contributes little to our specialized understanding of urban and economic development in the nineteenth century. In Nature's Metropolis, urban and economic history seem only to serve the interests of environmental history. Indeed, to Cronon, Chicago was, above all, "Nature's Metropolis," the economic motive force by which a rich natural hinterland of "first nature" was encountered, developed, exploited, and eventually submerged under an artificial "second nature" (56).

Yet the book makes significant theoretical and substantive contributions to both economic and urban history by placing urban and economic development in an environmental context. Because the city generated and mediated the forces that accelerated and transformed the interaction between humans and nature, Cronon needed to explain how urban development interacted with nature and distanced people from it. Urbanization, therefore, had to be articulated and explained, rather than assumed or viewed as an insular phenomenon with little reference to its regional context. As a result, Cronon has, perhaps inadvertently, brought urbanization as a "process" forward from its current relegation as a kind of assumed stage set for monographs on local occurrences in cities.

By explaining the dynamics of Chicago's development from different disciplinary, temporal, and spatial perspectives, Cronon ties together many loose threads in our understanding, discovers nuances and convergences, raises new questions, and makes provocative suggestions for further analysis. For Cronon, urban development becomes a broad, synthetic, integrating process through which modern life emerged. Thus, he reminds urban historians of the interdisciplinary nature of 
urban studies that initially created excitement about the field. In a field that seems to be drifting the way of the cities themselves, losing form and focus and thus centrality in the issues confronting American society and politics, Cronon demonstrates that thinking through the complexities of urbanization can enrich our understanding of the central role that process played in the social, economic, and political transformation of modern America. ${ }^{5}$ As a work of synthesis, Nature's Metropolis, ranging across specialized topics, fields, and disciplines, and referring to numerous towns, cities, and regions beyond Chicago, encourages us, above all, to resist the impoverishing impact of academic particularism or narrowness.

The rise of the metropolis was, above all, a regional process. In order to sustain their development, metropolises constructed transport systems to draw in the raw materials, human resources, and capital of a larger hinterland while reorganizing the economic life of the hinterland by providing markets and goods and services. As others, including myself, have argued, to really understand how and why cities developed, one must study how they organized their hinterlands. Cronon's study of Chicago demonstrates the explanatory power of this fundamental urban historical premise, one upon which the synthesizing power of urban history relies.

Yet the boundaries between urban and rural history, between city and hinterland, remain steadfastly drawn. In the Midwest in particular, a spate of more than twenty recent monographs on Chicago has tended to sharpen the boundaries between the history of Chicago and the history of the Midwest. There is some danger that Nature's Metropolis will be viewed as another book primarily about Chicago, perpetuating the cleavage in the literature between Chicago and its region. Yet by dissolving the boundaries between urban and rural history (7), and integrating city and hinterland history into a systemic regional history of the Midwest, Cronon has put the Midwest back into our historical understanding of Chicago. Equally important, he has put Chicago back into our understanding of the history of the Midwest. The former provides a subtle and

5. See Kathleen Neils Conzen, Michael H. Ebner, and Russell Lewis, eds., American City History: Modes of Analysis (Chicago, 1993). 
unique explanation of Chicago's astonishing rise and fall as a "gateway" metropolis. The latter provides, more importantly but less explicitly, a new metropolitan framework that demarcates the history of the region according to the changing character of the interactions between the metropolis and its hinterlands. That framework reinvigorates, from a different perspective, traditional themes in the history of Iowa and the Midwest.

Among Cronon's achievements, the establishment of this regional metropolitan framework is perhaps the most significant. It redefines the region and integrates local, regional, and national history into a unified whole. Yet Cronon focuses so much attention on Chicago itself that the history of the hinterland, though ever present, remains implicit. In the remainder of this essay I would like to make Cronon's analysis of developments in the hinterland more explicit in order to highlight the real contribution he makes to the history of the "Great West." I will do this by setting Cronon's demarcations of Chicago's interactions with its hinterlands into my own understanding of economic and social developments across Chicago's western hinterland between 1830 and 1880 . That interaction occurred in three stages. During the first phase, between 1840 and about 1865, Chicago established its primacy and began to rise to metropolitan dominance. It consolidated and maintained its hegemony during a second phase in the 1860 s and 1870 s. The dissipating of Chicago's control of its hinterlands in the mid1880 s suggests a third phase, characterized by more diverse and creative responses from the hinterland. This period prefigured a regional hinterland revival, focused primarily in the towns and cities, that developed in the late 1890 s and persisted through World War I.

Chicago, Cronon argues, emerged from its trading post function in the 1830 s to become a trade center for local farmers and a supply center for travelers and immigrants to the West. Its location on Lake Michigan gave it the cheapest and most direct connection of any place in the West to the urban capitalist system of the East. Boosters and speculators argued that its location destined it to become the funnel through which eastern capital would flood the region, making it the driving force of the region's growth and the center of some imagined "metro- 
politan empire" (53). But it was not until 1848, with the opening of the Illinois and Michigan Canal, that Chicago was able to command a substantially larger hinterland than an average market town. Within a year or two, Chicago's higher prices attracted much of the burgeoning surplus of corn from the Illinois valley down to Quincy's hinterland, pushing it ahead of competitors and fueling the ambitions of its merchants.

Cronon describes Chicago in 1850 as the center of a burgeoning urban empire, expanding the edge of the frontier and allowing historians to "read Turner backwards" (51). Despite Chicago's advances in the late 1840s, that judgment seems premature. Weak transportation links and competition from other towns to the west and south limited the expansion and consolidation of Chicago's hinterland. In fact, that process did not take place in frontier conditions. Within a hundred miles of the rivers, farmers had imposed new patterns on the grasslands of the prairies, and a well-established system of river towns encouraged settlement, stimulated market agriculture, and integrated a regional network of trade centered at St. Louis. This trade network, held together by a system of steamboats, had developed entirely without the aid of the metropolis on the lake.

The rise of Chicago as an entrepôt did, however, have an effect. As settlement spread beyond the range of the river markets, discontent with transport inefficiency spread. Merchants and farmers began to look eastward to Chicago. The initial construction of the railroads across Illinois into lowa relied more on the receptiveness of people in the hinterland than it did on capital from Chicago or the East. Western Illinois and Iowa, it must be admitted, welcomed their metropolitan invaders with open arms.

Nonetheless, once Chicagoans and their eastern supporters saw how the railroads could tap a pent-up demand for a market outlet and draw much of the burgeoning agricultural production to their market, they supported the railroads. Suddenly, it seemed, Chicago, with its access to several efficient corridors of transport, had a much broader hinterland of much greater richness than any other city in the country in the 1850s. The extension of the railroad system after the Civil War to the edges of the Great West, and even across the Rockies to the Pacific (a part of the story Cronon does not tell), unleashed eco- 
nomic and geographic forces that prompted the emergence of a "gateway" metropolis and transformed the reciprocal, egalitarian relationship between it and its hinterland.

Cronon argues that the railroads, as "pool[s] of capital designed to make more capital," imposed a new "capitalist logic" on the economic geography of the West (81). Steamboats had set transport rates from season to season in direct relationship to the cost per unit of weight of making the shipment. But because as much as one-third to one-half of all railroad costs. were fixed, railroad rates were set primarily to attract business to the line and to encourage customers to ship their goods as far as possible. As rates increasingly diverged from any relationship to cost, a geographic logic imposed itself on the system, favoring heavy-volume long-haul customers and cutting corridors or "faults" (65) of preferential access across the Midwest leading to Chicago and thence to the East. The unique monopoly Chicago railroads acquired over the hinterland funneled vast supplies into Chicago from the hinterland, generated unforeseen efficiencies and innovations, and enabled the city to control markets east and west. No city before, or perhaps since, has ever had such a monopoly over such a rich hinterland, and thus no city has been such an intense vortex of trade, capital, development, innovation, and growth.

Rather than constructing detailed graphs or maps demonstrating the emergence of these low-rate corridors and then tracking the increased volume of traffic as the railroads spread across Iowa before 1870, Cronon examines the effect of this building "deluge" of wealth at its terminal point in Chicago. Unable to handle the increasing volume of arriving grain, grain handlers in Chicago initiated a series of innovations. The timing of those innovations provides convincing, if circumstantial, evidence for Cronon's argument. By the mid-1850s, open bin storage in grain elevators had replaced sacks. This change forced grain handlers to segment and grade the grain, thus separating specific sellers from buyers. By 1859, Cronon argues, wheat had become a "liquid" commodity, allowing grain elevators to "sever the link between ownership rights and physical grain, with a host of unanticipated consequences" (116). Eventually, receipts and contracts replaced actual wheat as items of exchange. The futures market further broke the links between 
the market and the physical product, as speculators and investors entered the market. Their presence generated a rising tide of capital development in Chicago's downtown. As the efficiency of Chicago's market increased, costs dropped further. Relying on this price advantage, Chicago's railroads pushed farther out onto the plains and captured new supply regions and markets.

The lumber and livestock trades paralleled these developments. In the lumber trade, the corridor of access was the lake, but the same rails that brought wheat into Chicago provided the remarkable access to western markets that drew lumber merchants to the city. An auction system, cash payments, and preferential shipping rates made Chicago the central lumber market for the West for twenty years after the Civil War. The flooded market, in turn, supplied the inhabitants of the frontier with low-cost building material. Although lumber never became as commodified as grain, transport advantages funneled the treasure of the north woods through Chicago with similar results.

The development of the meatpacking industry also took advantage of the rail connections between the hinterland's supply and its markets. Chicago thus became a central node in a larger system of corporate vertical integration, both backwards toward the source of raw material and forward into the marketplace for dressed beef. Low rail rates made it profitable to ship hogs and cattle directly to Chicago. Economies of scale in a mechanized "disassembly" system and external economies generated by the sale of refuse enabled producers to undercut local butchers around the country. After Swift set up an integrated system of transport, service, and wholesaling through branch houses, the company came to dominate most local markets outside of New York City. By the early 1880s, four leading companies did 90 percent of the packing in Chicago, and the oligopoly controlled the national market.

Each product-grain, lumber, and meat-became merely a unit of value in a stream of resource acquisition, processing, production, and exchange. As these systems broadened geographically, they, like the railroad corporations, developed complex bureaucracies and communication and marketing systems, concentrating capital in Chicago and creating a pool of 
new capital upon which finance and banking institutions relied. By the 1870s, as Cronon's remarkable credit maps of the Midwest show, Chicago had become a great center of capital, with credit relationships spread across its hinterland. Still, the majority of creditors of Chicagoans were other Chicagoans, and even in its hinterland New Yorkers continued to provide significant amounts of capital by financing business and infrastructural development. Rather than deepening its ties with its hinterland beyond the transport, supply, and production systems already in place, Chicago seems to have reinvested its capital in its own development. Increasingly, it became an economic island in the region. Whether Chicago itself became an exporter of capital, loaning to those beyond its hinterland, Cronon does not explore; but in noting the sparse evidence of debtors farther West, he provocatively implies some of the reasons Chicago peaked in the 1880 s and remained, until it slipped a notch in the recent past, the "second city."

Chicago's rise established common or parallel experiences among a variety of places within its reach. In that sense, Chicago "created" a new hinterland, and with it a new region. Cronon's references to the hinterland are often generalized and abstract, punctuated only occasionally by specific examples of Grangers or lumber merchants in revolt, or merchants in Iowa or Nebraska doing business in Chicago's shadow. Nonetheless, his discussions of "prairie soils, steel plows, grain elevators, feedlots, cattle cars, and railroad rates" (268) delineate broad patterns of experiences and relationships that suggest a thematic framework for the history of the region, and of Iowa in particular.

Many merchants in Iowa and elsewhere within the hinterland urban system of the 1850s thought the railroad connections to Chicago would foster centrality and autonomy rather than dependency for their towns. The railroads did, in fact, initially raise prices, increase income and land values, and stimulate urban growth. ${ }^{6}$ After 1865 , however, the railroad system pushed west across Iowa, broadening its functional needs and flattening its rate structure. That expansion had unforeseen

6. See Timothy R. Mahoney, River Towns in the Great West: The Structure of Provincial Urbanization in the Midwest, 1820-1870 (New York, 1990). 
effects on eastern Iowa. Cronon notes that low rates gradually pushed a broad zone of corn and hog monoculture across the state. Prices dropped under the pressure of huge volume in the marketplace, forcing farmers deeper into debt to buy the machinery necessary to produce enough to make a profit. Mechanization began to squeeze workers off the farms, slowing population growth until the 1890 s, when it began a real decline. As the railheads moved west, each former railhead lost its depot function and the warehouses, hotels, stores, and restaurants that went with it. Meanwhile, long-haul rates from central Iowa encouraged farmers to ship directly to Chicago, bypassing local river town merchants. Wheat merchants and flour millers, forced to compete against Chicago, went out of business. Once vibrant local economies-already softened by the financial crashes of 1857 through 1859, the aging of the river town elites, and out-migration during the war-were turned into "mere way points on trunk lines serving the lake cities." 7 Low-cost wholesalers, agents, drummers, and traveling salesmen from Chicago found, in the 1860 s, a relatively clean slate upon which to draw the "blueprint" of a new regional order (269).

As the mixed blessings of access to a strong steady market became more apparent, occasional challenges or creative responses arose from the provincial gloom that, as Cronon portrays it, pervaded western Illinois and Iowa during the last quarter of the nineteenth century. The region was indeed populated by overworked, isolated, impoverished farmers who, in the words of one observer, were "bled almost to depletion" by paying annual tributes to Chicago (367) and who had an "exceedingly ambivalent," bitter, resentful, and angry attitude toward Chicago. Yet in their midst there were a few activists whose primary goal was not to sever the relationship, but to make it more equitable, competitive, and democratic. In the 1870 s the Grangers responded to high railroad rates in a period of low prices by seeking to end corruption in Chicago, regulate railroad rates, eliminate middlemen, and form cooperatives. Reformers also sought to encourage competition through the improvement of waterways, whether canals or the Mississippi

7. George H. Miller, Railroads and the Granger Laws (Madison, WI, 1971), 99. 
River. An 1877 pamphlet argued that since "the rate by river determines the rate by rail," Mississippi River transportation should be improved to increase competition. ${ }^{8}$ The same logic underlay most of the efforts to build local rail lines across the outer Midwest during the period.

Soon, the very concentration of forces that had made Chicago the dominating center began, in the 1880 s, to work against it. Diseconomies of scale, changes in the setting of rates in the lumber industry, spreading markets to the West, the development of fast freight around Chicago to the East, and competition from other lines across the West all worked to dissipate the vortex of forces that had given Chicago its dominance. As the system became more diffuse and porous, those in the hinterland found their options widening and diversifying. Farmers sold in different markets, merchants bypassed Chicago and purchased from a variety of markets, and travelers used the rail lines to interact with all parts of the country. Traveling salesmen and drummers from firms in the East competed actively with Chicago-based salesmen. ${ }^{9}$ Manufacturers began to set up plants across the Midwest, sparking local bursts of manufacturing that sought integration into a regional system centered in Chicago. Rural free delivery and mail order catalogs, although Chicago-oriented, improved farm life, raising material expectations, reducing isolation, and stimulating town life. Though often viewed as an era of loss, resentment, and bitterness, much creativity reemerged from the monocultural hinterland during this period. Residents used the city, as Cronon rightly notes, to improve and modernize their lives. ${ }^{10}$ The metropolis, though hated and resented by many, could be selectively encountered; one could draw from it what one wanted or needed and avoid or resist what one did not. In any case, country and city, Cronon concludes, had become parts of the same modern culture.

8. Give Us an Unobstructed River: A Memorial to Congress to Secure an Adequate Appropriation for a Prompt and Thorough Improvement of the Mississippi River (St. Paul, 1877), 5.

9. See Olivier Zunz, Making America Corporate, 1870-1920 (Chicago, 1990).

10. See also Andrew R. L. Cayton and Peter S. Onuf, The Midwest and the Nation: Rethinking the History of an American Region (Bloomington, IN, 1990), 116-23. 
Chicago's rise and fall created, in sequence, several phases of hinterland interaction. Each phase formed a specific historical moment, and each had a mix of negative and positive effects on the life of urban and rural hinterland. By identifying these shifting relations from the viewpoint of the metropolis, Cronon has created the framework for a broader history of the western hinterland. Rather than feeling threatened by Chicago's reemergence as a dominant force in the historiography of the region, historians of the Midwest should welcome the clarification of Chicago's role as the context in which to explore a diverse and varied history, as full of resistance, creativity, and assertive action as it was of parochialism, defeatism, and provincial decay. As Chicago rose and fell, so too did all of the positive and negative effects it had on its hinterland, giving that hinterland a history distinctive and very much its own.

\section{DAVID B. DANBOM}

It is easy to see why William Cronon's new book, Nature's Metropolis: Chicago and the Great West, deserves the special treatment the Annals of Iowa has chosen to give it. It is impressive for its breadth and its imaginative sweep. It is impressive as well for its ability to explain the arcane and difficult with clarity and grace. Such issues as railroad rate structures and the workings of futures markets are commonly glossed over by historians because understanding such matters is difficult and explaining them to others is harder still. Cronon handles intricate phenomena with grace, patience, and real insight, and his elegant prose makes it all look easy. Just a few years ago American historians were asking whether it was possible to join a pleasant and enjoyable narrative together with rigorous scholarship. In Nature's Metropolis William Cronon convincingly answers that question in the affirmative. For agricultural and rural historians in particular, Cronon offers a new way of looking at old things, an old way of looking at old things, and a perspective on the agricultural experience in the Midwest-and, logically, just about everywhere else-that challenges the whole way we view and judge agriculture and the rural past. 
The most important new perspective Cronon offers, it seems to me, involves the application of insights from Alan Trachtenberg's The Incorporation of America to the production and consumption of food. ${ }^{11}$ Trachtenberg suggested that American culture and society in the late nineteenth century were becoming "incorporated." By that he meant in part that the country was coming to be suffused with commercial and material values. But what he mainly meant was that, just as the shareholders in a corporation are separated from its workings, so, too, were Americans separated from the realities of existence in an increasingly complex and intricately structured social, cultural, and economic milieu.

Cronon shows how Chicago-representing Trachtenberg's industrializing America-separates producers of grain and meat animals from their products. He shows how grain, like almost everything else in a commercial setting, becomes a commodity, how individual farmers lose their identification with their own grain, and how this basic product-literally the staff of human life-comes to be a form of money, represented by paper, and an item that most people see only in the form of morning toast or dinner rolls. Likewise, meat is transformed by Chicago from living animals-raised, lived with, and in some way "known" by farmers-into attractively packaged steaks, roasts, and chops purchased by consumers who can easily suppress the knowledge that other beings died for their pleasure.

Certainly, others have recognized that agricultureespecially in the modern day-separates farmers and consumers from reality. Before Cronon and even Trachtenberg, for example, John Shover made this point with power and elegance in First Majority-Last Minority. ${ }^{12}$ But what Cronon does is to inject an element of morality into this process that others have not seen. For him, there is a sort of complicity between farmers and consumers, who tacitly agree to "incorporate" the process of producing and eating meat in order to avoid the personal moral responsibility for killing living things. Cronon implies

11. Alan Trachtenberg, The Incorporation of America: Culture and Society in the Gilded Age (New York, 1982).

12. John Shover, First Majority-Last Minority: The Transforming of Rural Life in America (DeKalb, IL, 1976). 
that this is a conspiracy in hypocrisy, and on one level he is right. On the other hand, James Turner would argue that the tendency of Victorians to separate themselves from the killing of animals indicated their growing sensitivity to the suffering of insentient beings. ${ }^{13}$ In either case, the issue is worthy of exploration, because it goes to the very core of human nature.

One old area of debate in agricultural history on which Nature's Metropolis makes an important contribution is that of commercialization. For a long time this was not much of an issue. For the Midwest, for example, Allan Bogue in From Prairie to Cornbelt seemed to illustrate to just about everybody's satisfaction that farmers were commercial from day one. ${ }^{14}$ Like Cronon's midwestern sons of toil, Bogue's were deeply interested in transportation facilities, processing, credit, land and crop prices, and so forth. They, too, accepted as natural (or "second nature," as Cronon would have it) that land, labor, crops, and animals were all commodities. In recent years, however, such rural historians as Stephen Hahn, James Henretta, Jonathan Prude, and Lacy Ford have identified a precommercial, or at least a pre-capitalist, rural America. In their rural America-which bears a close resemblance to the rural Europe of the Annales school-land, labor, and crops were not mainly commodities, the community made important decisions and enjoyed wide access to nature's bounty, and a sort of "moral economy" governed human relationships and exchange. ${ }^{15}$ For these rural Americans, such a symbol of commerce and capital as the railroad was less an enabler and a liberator than an enslaver. It was one of those forces-others, depending on the time and place, were water-powered mills,

13. James Turner, Reckoning with the Beast: Animals, Pain, and Humanity in the Victorian Mind (Baltimore, 1980).

14. Allan G. Bogue, From Prairie to Cornbelt: Farming on the Illinois and Iowa Prairies in the Nineteenth Century (Chicago, 1963).

15. See, for example, James Henretta, "Families and Farms: Mentalité in PreIndustrial America," William and Mary Quarterly 35 (1978), 3-32; Steven Hahn, The Roots of Southern Populism: Yeoman Farmers and the Transformation of the Georgia Upcountry, 1850-1890 (New York, 1983); Steven Hahn and Jonathan Prude, eds. The Countryside in the Age of Capitalist Transformation: Essays in the Social History of Rural America (Chapel Hill, NC, 1985); and Lacy K. Ford, Jr., Origins of Southern Radicalism; The South Carolina Upcountry, 1800-1860 (New York, 1988). 
fence laws, and property taxes-that doomed the moral economy and made people pawns of the capitalist one.

Nature's Metropolis will not have much direct effect on this school of rural historians, because its focus is on the Midwest while theirs is on such places as colonial New England and the antebellum southern piedmont. What Cronon does show, though, is that the people who came to Chicago's hinterland were not reluctant commercialists, whether they came in 1840 or 1860 or 1880 . They came with the expectation of participating in a market economy and wouldn't have stayed had that expectation not been met. This is not to say that they were always happy with their rewards in that economy or that they thought it always treated them fairly; as Cronon points out, they were often disgruntled about the way things unfolded. But those who follow Cronon will be hard pressed to argue that midwestern farmers were dragged, kicking and screaming, into capitalist agriculture.

Those who follow Cronon will also find it difficult to argue, as farmers and agricultural historians both like to do, that farmers are mere pawns of forces beyond their control. It is true, of course, that rivers freeze and wheat rusts, market prices fluctuate and middlemen use their economic strength to their advantage. Cronon doesn't dispute any of this. What he does do is to show, convincingly to my mind, how Chicago and the farmers of its hinterland were coconspirators in the imposition of "second nature" - of farms and railroads and towns and cultivars and domesticated beasts-on the Midwest. This brings me to the most interesting and challenging aspect of Nature's Metropolis, from my perspective, its environmental moralism.

Cronon questions the alteration of the environment of the Great West-whether it be the cutting of the white pines, the breaking of the tallgrass prairie, the destruction of the buffalo, or the introduction of cattle on the plains-not from the point of view of utility or wise resource use, but from the point of view of morality. He implies that it was immoral-virtually a sin-to disturb first nature and impose second nature upon it, and that all of us were, and are, responsible-or guilty-for this act. Chicago and its hinterlands were guilty in the nineteenth century and we are guilty today if we eat western beef or 
pork or bread or travel the interstates or vacation at Wisconsin lakes or do any of a thousand other things.

Certainly, agricultural and rural historians trade in guilt and morality just as do their colleagues in other subdisciplines. They commonly condemn those who dispossessed Native Americans and enslaved African-Americans. They often pass moral judgments on speculators, railroaders, bankers, landlords, middlemen, and large farmers. But they are not accustomed to passing harsh moral judgments on all farmers. Perhaps agricultural historians, like many in our society, cling unconsciously to a vision of rural superiority. We do tend to think of farmers as good people who work hard producing things of intrinsic value that all of us need to sustain life. When we think of farmers' relationship to nature, we recognize that they subdued the wilderness and made it fruitful, but that, after all, was ordained by the Judeo-Christian God. And sometimes we are willing to agree that they contributed to environmental problems, such as the Dust Bowl, through their ignorance. More commonly we think of them as Jefferson thought of them, as nature's noblemen, working in and with nature to meet human needs.

Cronon is unwilling to let farmers - or any of the rest of us-off the hook. To him, farming is not a "natural" occupation. In its very essence it is an intrusive enterprise that disturbs the natural environment to a greater or lesser degree. This was one of the lessons of his first book, Changes in the Land, and he brings it home subtly but forcefully here. ${ }^{16}$ Indeed, for him, farmers are hypocritical as well as immoral. Not only are they as guilty as Chicago of ravaging first nature, they compound their offense by posing as morally superior to the city.

In a sense Nature's Metropolis reminds me of Donald Worster's Dust Bowl. Worster, too, emphasizes farmers' destruction of the natural environment, but in Worster's case capitalism is the culprit. ${ }^{17}$ Greedy people break fragile lands because they are driven by a vision of commercial success, and in the

16. William Cronon, Changes in the Land: Indians, Colonists, and the Ecology of New England (New York, 1983).

17. Donald E. Worster, Dust Bowl: The Southern Plains in the 1930s (New York, 1979). 
resulting catastrophe they and their lands are both swept away. Cronon might agree that capitalist dynamism would speed up the process, but for him morality inheres in the act itself rather than in the motivation for it.

What Cronon is doing is introducing into history a dramatically expanded conception of morality in which humanity is simply one component of the natural community, and not a component that is morally superior to others or that has a right to manipulate them. It is appropriate that Cronon precedes his prologue with a quotation from Aldo Leopold's Sand County Almanac, because Leopold's "land ethic" - the belief that we are but a part of a biotic community that encompasses all living things, including the soil-underlies many of the assumptions of Nature's Metropolis. ${ }^{18}$ The land ethic and the sensitivities it expresses has made a good deal of headway in the environmental movement. That is one reason, by the way, why policymakers find some environmentalists to be moralistic and uncompromising. It has also been applied to agriculture, by Wes Jackson among others. ${ }^{19}$ And it has shown up in the work of environmental historians, such as Cronon, who are, as one might expect, usually sensitive environmentalists in addition to being scholars. As far as I am aware, however, Cronon is the first historian to apply the judgments and assumptions of the land ethic to agriculture in a direct and systematic fashion.

Whether Cronon's introduction of the land ethic will have much impact on agricultural historians in the next few years will be interesting to see. Most historians, like most other people, are accustomed to defining morality in human terms. For us, history is mainly a record of human life, and when we think of injustice or immorality, we think of it in terms of the relationship of people to one another. Certainly, we are civilized beings who have a reasonably well-developed facility for empathy, so we don't like to see creatures biologically close to us, such as domesticated animals, treated with gratuitous cruelty. But I don't believe that most agricultural and rural historians, or

18. Aldo Leopold, $A$ Sand County Almanac, and Sketches Here and There (New York, 1949).

19. See, for example, Wes Jackson, New Roots for Agriculture (San Francisco, 1980). 
most of the other readers of Nature's Metropolis either, are ready to extend their definition of community to include all living things. Should we do so, we would be forced to alter our view of farmers and agriculture and to reject as trivial most of the questions we have asked about the rural past. More fundamentally, we would be forced to alter dramatically an ethical stance rooted deeply in Western culture. A point of view appropriate to environmental history and relatively easy to apply to environmental issues, then, will not help most agricultural historians answer the questions they want to ask.

It is the moralism of Nature's Metropolis that makes it such a compelling book, as opposed to being merely a very interesting one. This is a book about evil unleavened by good, about sin without redemption, about guilt and about complicity. But I am inclined to believe that most agricultural and rural historians will appreciate it mostly for its discussions of marketing, processing, and credit, its explanation of the relationship between the metropolis and the hinterland, and its contribution to the debate on commercialization. I think that they will find the moral stance of Nature's Metropolis challenging, stimulating, and perhaps irritating as well. I don't think it will compel them to alter their understanding of agricultural and rural history.

\section{PHILIP V. SCARPINO}

In 1949 Oxford University Press published $A$ Sand County Almanac and Sketches Here and There by Aldo Leopold, one of the most important books written in the twentieth century on the interplay between human beings and nature. Leopold grew to adolescence in Burlington, Iowa, where he developed an appreciation for nature and a budding environmental ethic that reached full bloom in $A$ Sand County Almanac. Leopold had a keen sense of history and of the importance of the intersection between natural and human history. In $A$ Sand County Almanac, he issued a call for an ecological interpretation of history. "That man is, in fact, only a member of a biotic team is shown by an ecological interpretation of history," he argued. "Many historical events, hitherto explained solely in terms of human enterprise, were actually biotic interactions between people and 
land. The characteristics of the land determined the facts quite as potently as the characteristics of the men who lived on it." ${ }^{20}$

Leopold's call went largely unheeded for about twenty years, when some historians began to examine the evolving relationship between people and the environment. Many of these historians took up the challenge of formulating an ecological interpretation of history. ${ }^{21}$ William Cronon's Nature's Metropolis: Chicago and the Great West continues and advances that line of enquiry. In so doing, Cronon tells a fascinating story of Chicago in the last half of the nineteenth century, a time when a small town became a great metropolis, attained preeminence as a "gateway" city, and controlled the flow of commodities and capital in a vast western hinterland that eventually reached to the Pacific. Focusing on commodity and capital flows, he points out the ecological bonds that united Chicago and its vast western hinterland. The face of the western lands and the form of the great metropolis depended absolutely on the exchange of products produced by nature's economy (livestock, corn and wheat, white pine) for those manufactured and distributed through the human economy (meat, flour, dimension lumber, farm machinery, consumer goods).

Cronon's story of Chicago and the Great West is constructed around an interpretive framework that is fundamentally ecological in its perspective. He describes an interconnected and interdependent system that integrates nature's economy and the human economy into a vast "second nature" that owes its geography to the flow of capital drawn on "first nature's" account. In common with the relationships found in a natural ecosystem, the various parts of second nature, which Cronon practically defines as capital, not only existed in mutual dependence but also frequently prospered at the expense of other elements in the system. Much of the narrative in Nature's Metropolis takes place at the interface between the human economy and nature's economy, which itself is a bedrock

20. Aldo Leopold, A Sand County Almanac and Sketches Here and There (New York, 1949; commemorative paperback edition, 1989), 205.

21. For a historiographical overview of environmental history, see Richard White, "American Environmental History: The Development of a New Historical Field," Pacific Historical Review 54 (1985), 297-335. 
ecological concept. Cronon argues that "if we wish to understand the ecological consequences of our own lives-if we wish to take political and moral responsibility for those consequences-we must reconstruct the linkages between the commodities of our economy and the resources of our ecosystem" (xvi).

It would be tempting to argue that historians were merely slow to recognize the fundamental importance of the environment in human history, but the more accurate explanation lies in the social context within which historians make history from the past for use in the present. Historians (and all other people who make history) look to the past with particular interests and questions in mind, which are shaped by the society in which they live. Not until the 1960s did an interest in the environment, rooted in a popularized understanding of ecology, become widespread among the people of the United States. One of the most important popularizers of an ecological perspective was Rachel Carson in her seminal book, Silent Spring (1963), which gave focus and form to public concerns about the largely unregulated use of DDT and other synthetic, organic pesticides and herbicides. Interestingly enough, sales of $A$ Sand County Almanac, which began slowly, took off in the late 1960 s as growing numbers of environmentalists sought both a scientific underpinning and a past for the new environmental movement. $^{22}$

Before the 1960s, the words environment and ecology were in very limited use, restricted largely to the natural scientific community. Embedded in these words, which we often use and infrequently define, is an understanding of nature and of the relationship between people and the natural world that was alien to most Americans before the 1960s. Hence, Leopold's call in 1949 for an ecological interpretation of history went

22. Rachel Carson, Silent Spring (Boston, 1962). The best historical analysis of the development of ecology is Donald Worster's Nature's Economy: A History of Ecological Ideas (New York, 1977). For an examination of the evolution of the post-World War II environmental movement, see Samuel P. Hays, Beauty, Health, and Permanence: Environmental Politics in the United States, 1955-1985 (New York, 1987), especially chapter 1. On sales of A Sand County Almanac, see Curt Meine, Aldo Leopold: His Life and Work (Madison, WI, 1988), 525-26. 
unanswered because the knowledge and perspective that would have informed such an interpretation were largely absent from American society until the mid-1960s. Historians started to write environmental history when the society to which they belonged began to manifest an interest in the environment. Beginning in the mid-1960s and continuing to the present, historians have explored the interplay between people and the environment, and in so doing, have made considerable progress in methodological and interpretive sophistication.

At about the same time that historians began to study human interaction with the environment, the discipline itself was undergoing substantial changes. In addition to calling attention to the environment, the social ferment of the 1960 s and 1970 s contributed to a reorientation of the profession towards the ordinary and everyday, which included both subjects and groups that formerly had not received much attention from academic historians. Along with this "new" social history revolution came growing specialization and fragmentation, a movement that was consistent with developments in other professions at about the same time. Historians concentrated on narrow slices of the past and communicated their scholarship to limited audiences composed mainly of colleagues in their own specialties. Environmental historians were no exception to this trend.

Nature's Metropolis sets a bold standard for breaking down the barriers of overspecialization. Cronon synthesizes several heretofore discrete fields of historical enquiry into a narrative that includes urban and rural history, along with western, economic, and environmental history. As with all history, the interpretive framework in Nature's Metropolis is constructed in the present. Cronon's emphasis on the unity of city and country, bound together by the commodification of biotic capital, is consistent with an ecological world view. Yet it is important to remember that the people of Chicago and the Great West acted in a way that made sense in their own time. In the nineteenth century, most people saw themselves as being in conflict with nature; they gauged progress by the rate at which they converted ostensibly inexhaustible resources into useful commodities; and they measured the advance of civilization by the reordering of the land to serve human needs. Indeed, the roots of 
the modern environmental movement are to be found in a response to the unintended or unanticipated consequences of the exploitation of nature in the last half of the nineteenth century.

In the continuing evolution of professional historical enquiry, public history has attempted to redirect the attention of historians toward communicating the results of their scholarship to broader audiences. Unfortunately, most environmental history continues to be a conversation among professionals; environmental historians have achieved little success in connecting their substantial scholarly achievements to the larger public discourse about the environment. Nature's Metropolis fits this trend; its bold synthesis is aimed at a largely academic audience. There is, however, much in this volume that could be repackaged in a form that would add to the public dialogue about the environment. One could easily imagine a very exciting museum exhibit based on Cronon's book that would make a major contribution to public scholarship.

In crafting a common history of city and country, Cronon insists that "my deepest intellectual agenda . . . is to suggest that the boundary between human and nonhuman, natural and unnatural, is profoundly problematic" (xvii). In taking this approach, he productively separates himself from other historians who have defined the proper purview of environmental history as "nature. ${ }^{\text {23 }}$ Most people would have little trouble seeing Chicago as a human artifact built from the bounty of nature's economy. But what was true of Chicago was also true of its hinterland. During the second half of the nineteenth century, the economic processes so carefully described in Nature's Metropolis stimulated the reshaping of Chicago's hinterland into a humanized landscape.

This process of environmental transformation continued throughout the twentieth century, so that in our modern, postindustrial society, most of what we call nature is really a human artifact, a cultural mosaic that reflects the changing and often conflicting values of the people who imposed their own

23. See, for example, Donald Worster, "Transformations of the Earth: Toward an Agroecological Perspective in History," Journal of American History 76 (1990): 1089-90. 
vision(s) of order on the face of the land. Even wilderness areas are human artifacts, preserved, protected, and managed by people who value these surviving fragments of our natural heritage in a way that not only would have seemed strange to most people in the last half of the nineteenth century but also that can trace its genesis to their attitudes and actions towards nature.

Railroads tied city and country together, extended Chicago's economic influence far to the west, and provided the commercial circulatory system for the city's vast western hinterland, which included Iowa. Railroads not only physically united city and country, but they also made possible the common history that Cronon has constructed for Chicago and the Great West. Although both market mechanisms and human rhetoric obscured the ecological connections between Chicago and its hinterland, many residents of Chicago and the Great West nonetheless recognized their mutual dependence. Recognition did not always mean approbation, and rural people in the last half of the nineteenth century often deeply resented what they viewed as the parasitic role of Chicago's "middlemen." As the editor of the Clinton Age explained in 1893, "Iowa has paid an immense cash tribute every year to Chicago, for a score or more of years, and no doubt always will continue to do so. The state has been bled almost to depletion by Chicago" (374).

During the last half of the nineteenth century, new developments in agricultural machinery, such as the McCormick reapers manufactured in Chicago, helped transform farming into a business, accelerated the reordering of the rural landscape, and augmented the impact that farming could exert on the environment. Reapers and other agricultural machines made it possible for farmers to meet and often exceed the demand generated by the railroad and the expanding markets in Chicago. Among the many useful maps in Nature's Metropolis are two that illustrate the distribution of McCormick reapers in 1850 and 1860 . Thanks to waterways and then to the expanding rail system, by 1860 reapers from the McCormick factory in Chicago enjoyed strong sales in the northern twothirds of Illinois and the eastern third of Iowa. 
By the 1890 s, fisheries scientists working in those same parts of Iowa and Illinois had begun to note that plowing the prairies and draining the wetlands had adversely affected the volume of flow in the state's rivers and streams and the species composition of fish. What Nature's Metropolis does so well is to show that the creation of a human habitat in Chicago was a part of the same process that humanized the natural habitat in Illinois and Iowa and the rest of the Great West. City life and country life both depended on nature; neither can be understood in isolation from the ecosystems that sustained them.

By weaving the environment into his larger story of Chicago and its hinterland, Cronon has elevated environmental history from an isolated subfield to an integral part of a broader analysis that explains the past to the present. Yet, for a study in which the environment plays such an important role, both the urban and rural environments are surprisingly abstracted. To be sure, there are exceptions, but in the main, the built environment of Chicago and the rural but increasingly humanized environment of the Great West become stages on which the story of commodities is acted out. Lake Michigan's role is to provide transportation for lumber and other products moving to and from Chicago. Three long and very detailed chapters on grain, lumber, and meat dominate the book, and here the market almost seems to take on a life of its own. Commodity flows move perilously close to determining the action, while people and the cultural values that they bring to their interactions with nature recede into the background.

Perhaps because commodities are the actors and the urban and rural environments are the sets, Nature's Metropolis has little to say about conservation, which also must have been a part of the common story of Chicago and the Great West. Conservationist sentiment built slowly in the last half of the nineteenth century and became a broad national movement in the early twentieth century. Conservation attracted most of its converts in urban/industrial areas such as Chicago. Although there was considerable disagreement over both the problems and the solutions, the common denominator was a response to the often unintended or unanticipated environmental consequences of the kinds of processes that are explained so well in Nature's Metropolis. Generally these responses fit within the 
nineteenth-century emphasis on using resources to promote material progress. A case in point was the growing popularity of fish culture and timber culture at the end of the nineteenth century. (Culture refers to growing and then planting or releasing trees or fish, with the intent of maintaining a harvestable surplus.) But throughout the second half of the nineteenth century there was also a growing segment of conservationists who put their emphasis on noneconomic aspects of nature, such as beautiful scenery or the restorative powers of nature for urban residents. ${ }^{24}$

Much has been written about conservation milestones such as the Report on the Disastrous Effects of the Destruction of Forest Trees Now Going on so Rapidly in the State of Wisconsin (1867), by Increase Lapham, et al., or the creation of Yellowstone National Park in 1872. ${ }^{25}$ Yet one might be able to demonstrate that these and other events that appear to be isolated in time and place actually fit into the same urban/rural model developed in Nature's Metropolis. By the early twentieth century, both the black cloud of coal smoke that symbolized Chicago's industrial prosperity and threats of industrial developments in nearby dunes along the Indiana shore of Lake Michigan prompted much conservation activity in Chicago. ${ }^{26}$ While most conservationists did not directly challenge the economic system that produced smoke and destroyed dunes, they were prepared to fight for clean air and the preservation of dunes as refuges from the smoke and other unhealthy or disagreeable qualities of Chicago's urban habitat.

By the mid-1920s, with the founding and rapid growth of the Izaac Walton League of America (IWLA), Chicago became the headquarters of a large conservation organization that

24. For an examination of the range of motives and goals represented among conservationists, see Samuel P. Hays, Conservation and the Gospel of Efficiency: The Progressive Conservation Movement, 1890-1920 (1959; reprint, New York, 1974); Roderick Nash, Wilderness and the American Mind, 3d ed. (New Haven, 1982), especially chapters 8-10.

25. On Yellowstone, see, for example, Alfred Runte, National Parks: The American Experience (Lincoln, NE, 1979).

26. J. Ronald Engel examines the interests of Chicagoans in the dunes along the Indiana shore of Lake Michigan in Sacred Sands: The Struggle for Community in the Indiana Dunes (Middletown, CT, 1983). 
received much of its support from the city's midwestern hinterland. The IWLA was founded in 1922 in Chicago by fifty-four business and professional men, led by an advertising executive named Will Dilg. What these men had in common was their love of fishing and their belief that the opportunity to enjoy the out-of-doors was rapidly becoming a casualty of continuing development. The IWLA struck a responsive chord among likeminded men, and in so doing, it attracted about 100,000 members by 1924 and around 175,000 by 1928 . On the one hand, men such as these were players in the process that created Chicago and transformed its rural hinterland. On the other hand, the rapid growth of the IWLA suggests a high level of concern over the environmental costs of that process. ${ }^{27}$

In 1924 the IWLA led a successful fight to have Congress purchase and protect the Upper Mississippi River Wildlife and Fish Refuge, which comprised overflow lands along the river between Rock Island, Illinois, and Wabasha, Minnesota. Iowans, such as those who belonged to the McGregor chapter of the IWLA, played a role in that victory. Although by the 1920s Chicago had lost some of its control over rural markets to other cities, this was an area that was relatively nearby, tightly bound to the city by rail connections, and viewed as a valuable recreation area by outdoor enthusiasts in the city. ${ }^{28}$ In Nature's Metropolis, Cronon argues that the multiple commodities in which Chicago dealt (including vice) had their own rural hinterlands. The experience of the IWLA suggests that the city might have had conservation hinterlands as well.

Nature's Metropolis offers a fresh, exciting, and provocative historical synthesis that incorporates environmental history into a broad analysis of the past in a way that few other studies have done. While it is not a casual read, it is a good one. Cronon pushes his readers to reimagine the role that the environment has played in a common story of the city and the country, and in so doing, he has added much to the present dialogue about

27. On the Izaak Walton League of America, see Philip V. Scarpino, Great River: An Environmental History of the Upper Mississippi, 1890-1950 (Columbia, MO, 1985), especially chapter 4.

28. On the Upper Mississippi River Wildlife and Fish Refuge, see Scarpino, Great River, chapter 4. 
the past that we call history. Good history should tell us about both past and present, and Nature's Metropolis does that very well. Readers will not only be challenged to rethink the history of Chicago and the Great West but also to reconsider the interplay between city and country, the relationship between people and the environment, and the environmental consequences of human actions in the present.

\section{RESPONSE: WILLIAM CRONON}

It's a real privilege to have one's work receive extended commentary of the sort that these distinguished historians have given it, and I'm very grateful to Marvin Bergman for having put together this special symposium in the Annals of Iowa. I'm particularly happy that Nature's Metropolis is receiving this sort of attention in a journal devoted to Iowa history, since one of my worries has been that would-be readers would mistakenly assume that only people curious about Chicago would find the book of interest. As Marvin Bergman indicates in his introduction, and as the four commentators each suggest in their different ways, the book's intended audience is in fact much larger. My hope in writing it was to suggest that one really can't understand the history of nineteenth-century Iowa-or of the Mississippi valley, the Middle West, or the West generally-if one fails to see those places, at least in part, as portions of Chicago's hinterland. I intended the book to make as much of a contribution to the history of Iowa as to the history of the city that has served as Iowa's metropolis.

Malcolm Rohrbough does a better job than I could have of summarizing the book's basic argument, so rather than repeat his synopsis, I'd like mainly to respond to the chief criticisms of these reviewers and reflect with them about the most important questions that the book leaves open for further research. I'm delighted that Rohrbough himself chooses to situate the book upon the larger terrain of American frontier history, since one of my not-so-hidden agendas in writing it was to launch a rearguard defense against those scholars-among whom my friend Patricia Limerick is undoubtedly the best known and most eloquent-who seek to expunge what Limerick calls "the 
F-word" from American history. In her justly celebrated book, The Legacy of Conquest, Limerick puts forward what she intends to be a purely regional vision of western history, arguing that scholars of the field should abandon their studies of American frontier settlement in favor of a comprehensive multicultural history of the lands beyond the hundredth meridian. ${ }^{29}$ In her view, the very word frontier is so freighted with ethnocentrism and racism that it is virtually unsalvageable as a category of historical analysis.

Although I agree with Limerick that frontier history has too often been written as a self-congratulatory paean to American expansionism, I share with Malcolm Rohrbough the conviction that Limerick's West is far from being the only West that should matter to American historians. Rohrbough himself has written the best one-volume synthesis we have of trans-Appalachian western history. ${ }^{30} \mathrm{He}$ reminds us that scholars who are interested in the general history of North American settlement-the movement of different peoples into the emerging regions of the continent-have traditionally seen western history as their natural intellectual home. This for me is the most valuable legacy of Frederick Jackson Turner's school of frontier history. It is the reason why historians of the Old Northwest, the Old Southwest, and the Middle West have traditionally joined their colleagues from beyond the grasslands of the Plains in a single scholarly endeavor called "western history." Historians of Iowa and of other areas that have since ceased to be "West" should understand that if the attack on "the F-word" succeeds, western history will no longer have room for them. ${ }^{31}$

29. Patricia Nelson Limerick, The Legacy of Conquest: The Unbroken Past of the American West (New York, 1987). Limerick in fact smuggles the frontier back into her supposedly pure regional history, since the word "conquest" describes a process of occupation and settlement-a frontierish sort of process-that extends well beyond the trans-Mississippi West in a way that Frederick Jackson Turner himself almost surely would have recognized, and maybe even applauded.

30. Malcolm J. Rohrbough, The Trans-Appalachian Frontier (New York, 1978).

31. The other solution would be for those who are trying to expunge the frontier from western history to admit that a region called the "Middle West" would not have that name if it were not in fact in the middle of the West-but I am not optimistic that this happy event will occur anytime soon! 
In my view, that would be a serious loss. One of the great attractions of western history has always been the comparative analytical foundation that Turner laid for it, a foundation that derived most of its strength from the frontier despite the many problems with Turner's own thesis. By examining the ways that colonization and settlement processes have occurred on the radically different landscapes of North America, western historians have been contributing for three or more generations to what one might call the "interior history" of the United States. Unlike national historians who often place too much emphasis on New York and Washington D.C., western historians have narrated our national history with full attention to all American regions (with the possible exception of the South). If western history were suddenly to shift entirely to the lands beyond the Plains-which certainly deserve full attention in their own right - the field would lose much of its interest for the inhabitants of other regions (especially the Middle West), and for historians who still seek to construct a narrative that attends to regional difference while nonetheless encompassing the entire nation. In addition, one can argue with considerable force that the history of places like Ohio or Iowa is indispensable for anyone who wishes to understand the history of regions farther west.

This is why I can only applaud Malcolm Rohrbough's suggestion that Nature's Metropolis begins its story in the middle, and that the questions it asks should be pursued backward in time and southward in space. He is certainly right that the postrailroad relationship of Chicago to Iowa was quite different from the city-hinterland connections that characterized places like Kentucky and Ohio. Despite the differences, I'm inclined to believe that the question of how city and country became tied together in regional markets is a useful way to understand frontier dynamics all the way back to colonial times. Indeed, I sometimes think of Nature's Metropolis as a natural sequel to my earlier book, Changes in the Land, which essentially described a comparable set of environmental changes that occurred in New England as that region became linked to London's markets and to the North Atlantic economy. By this reading, colonial history and frontier history form an almost seamless continuum. 
As Rohrbough rightly suggests, Nature's Metropolis is by no means the last word on the frontier connections of city and hinterland. He shrewdly points to the Old Southwest as a region whose frontier economy experienced a very different course of development from that of the Old Northwest, and we still have surprisingly few comparative studies that explore with rigor the reasons for their differences. Southern history is, of course, one of the most sophisticated of all subfields in American history, with an enormous historiography in its own right, and this has probably discouraged many western historians from engaging it more directly. As Rohrbough notes, however, the benefits of doing so are enormous, since few topics in comparative regional history are likely to be as rich.

Whoever pursues this theme will want to study with care the important contributions that Timothy R. Mahoney has made to the study of regional dynamics in the Mississippi valley, both in his comment for this symposium and in his own work on lowa's river towns. ${ }^{32}$ Mahoney is right to assert that Nature's Metropolis does not do full justice to the lives of farmers and townspeople in Chicago's hinterland. My purpose in the book was to try to capture in very broad brush strokes the most important connections between city and country, but this had the almost inescapable consequence of giving my descriptions the rather distant and abstract quality of a bird's-eye view. (Philip Scarpino joins Mahoney in critiquing this aspect of the book.) In my own partial defense, I would argue that the bird'seye view has a number of virtues. It reveals large-scale relationships and processes in ways that are much harder to see when one is closer to the ground. It can be an ideal vehicle for synthesis and for highlighting the mechanisms of urbanization and environmental change that were my principal subject in this book.

But certainly the bird's-eye view needs to be complemented by the more fine-grained treatment that Mahoney him-

32. Timothy R. Mahoney, River Towns in the Great West: The Structure of Provincial Urbanization in the American Midwest, 1820-1870 (New York, 1990); idem, "Urban History in a Regional Context: River Towns on the Upper Mississippi, 1840-1860," Journal of American History 72 (1985), 318-39; and idem, "Down in Davenport," Annals of Iowa 50 (1990), 451-74, 593-622. 
self has given the Iowa river towns and that his current studies of midwestern provincial culture possess as well. I very much like his suggestion that midwestern regional changes occurred on different timetables and had different impacts depending on who one was and where one lived. Like Mahoney, I believe we can acknowledge the centrality of Chicago to the midwestern urban system without treating the metropolis as if it were hegemonic. Knowing more about how farmers and townspeople in places such as Iowa responded to Chicago's changing influence would be a valuable corrective to the metrocentric story of Nature's Metropolis.

I might quibble with only a couple of Mahoney's comments. On a very technical point, I think he misreads the evidence from my bankruptcy statistics. when he concludes that Chicagoans were unusual in spending so much of their money within the bounds of their own city. Although I haven't conducted an analysis of other metropolitan centers to know this for certain, my suspicion is that the higher one goes in the urban hierarchy, the more one will probably find this internal metropolitan cycling of capital. If one did a comparable analysis of New Yorkers in the nineteenth century, I suspect one would discover that a sizable share of their commercial transactions were with other New Yorkers-much like Chicagoans. The metropolitan economy being what it was, people and firms were able to buy more supplies from their neighbors than was typical in smaller cities. I'm therefore not at all sure that it is appropriate to describe Chicago as an "economic island" that somehow failed to deepen its ties with the region. Chicago's hinterland certainly contracted after the 1880 s because of competition from other urban markets, but the city remains to this day intimately involved in the economic life of rural and smalltown residents from Indiana to Iowa and beyond.

I'm also a little troubled by Mahoney's second paragraph, in which he seems to suggest (perhaps only for rhetorical effect, in which case this comment may be misplaced) that Nature's Metropolis subordinates the interests of economic and urban history to those of environmental history in a way that may limit its relevance to these other fields. Although he generously goes on to say that the book does make a contribution to our understanding of urbanization, he seems to think that this con- 
tribution may somehow have been inadvertent. My concern here is not to defend my own originality, for the book could not have been written without many borrowings from other disciplines and scholars, including Mahoney himself. Rather, I'm troubled that he seems to think that the interests of environmental historians may be antithetical or at best tangential to those of economic and urban historians.

I'm not at all sure why this should be the case. One of my most important agendas in Nature's Metropolis was to try to convince environmental historians that the city is among the most important historical loci of environmental change, and that they must therefore grapple with urban history if they wish to understand their own subject. Surely such an argument can only strengthen the claims of urban history as a field, setting the process of urbanization in a broader context that is as important to urban historians as it is to environmental ones. In much the same way, I have tried to argue in both of my two books that economic history and environmental history have extensive areas of overlap, and that neither can be properly understood if one ignores the other. Nature's Metropolis tries to demonstrate that the dynamics of environmental change make little sense if you don't take markets and economics seriously; but I also believe the converse to be no less true. My own inclination is to think that these sorts of boundaries among subfields often do more harm than good. As Mahoney says, it's important "to resist the impoverishing impact of academic particularism or narrowness."

I have a similar reaction to David Danbom's comment. I'm quite surprised that he sees such a powerful opposition between the approaches of environmental and agricultural historians-especially since I sometimes use both labels to describe myself! It is certainly true that I and many of my colleagues in environmental history tend to see agriculture as a complex series of relationships between people and the many organisms that either help or hinder the human effort to raise food. As one might expect, such a perspective encourages us to reflect on the consequences of agriculture not just for people but for other creatures as well. We cannot help but acknowledge, for instance, that the extraordinary achievements of frontier farmers in settling the grasslands of the Middle West had 
the consequence of virtually eliminating the tallgrass prairie as a significant element of the North American landscape. I make this point several times in Nature's Metropolis, and do so in what might be called an elegiac tone. It seems to me that the prairie is a world we have lost, a world that is worth remembering and respecting in its own right.

At least to my mind, however, an elegiac lament on behalf of a lost landscape is very far from saying, as Danbom apparently believes I wish to do, that "it was immoral-virtually a sin-to disturb first nature and impose second nature upon it." I believe nothing of the sort, and am surprised that Nature's Metropolis can be read in this way. And yet Danbom is not alone in finding this message in the book, which means that I have apparently done a poor job of communicating what I thought was the most important argument of my own book. ${ }^{33}$ In the prologue and epilogue, where I reflect very broadly on the meaning of Chicago's growth and the environmental transformations it helped cause, I argue that people cannot help but alter the world around them as they pursue their collective life. I specifically distance myself from "deep ecology," whose proponents come close to arguing that we should abandon civilization altogether in order to preserve nature and return to a better, more primitive life in the wilderness. People who believe this, I wrote in the book,

fail to see that our own flight from "the city" creates "the wild" as its symbolic opposite and pulls that seemingly most natural of places into our own cultural orbit. We alter it with our presence, and even with the ways we think about it. Just as our own lives continue to be embedded in a web of natural relationships, nothing in nature remains untouched by the web of human relationships that constitute our common history. And in that fact lies the measure of our moral responsibility for each other and for the world, whether urban or rural, human or natural. We are in this together (18-19).

33. One reviewer who offers a similar argument in a much more hostile and ad hominem way is Peter A. Coclanis, "Urbs in Horto," Reviews in American History 20 (1992), 14-20. 
This is not a passage about evil, or about environmental atrocities that people have supposedly committed against pristine nature. Rather, it is about moral responsibility in a world where few of our actions are unambiguously good or bad. It is about the common ground that nature and humanity occupy together, first and second nature inextricably mingled with one another. Those like Danbom who read the book as an environmentalist tract should know that many radical environmentalists are likely to attack it from the opposite direction for being too sanguine about the city and about human alterations of the natural world in general. At a recent conference, one annoyed environmentalist accused me of being "pathologically evenhanded," and since I almost took it as a compliment, I guess I should probably plead guilty. I do not believe it is possible to live in the world without changing it. Farmers must break the sod in order to grow food; they must transform the natural world if people are to eat. All of our lives depend on their labor, and I am very much on their side. No question of sin is involved here.

Environmental historians would nonetheless argue that one key task of agricultural history is to try to understand the relationship of people to food, and of food to the earth, in a systemic way. If anything, such an approach makes it harder to moralize, not easier, since villains and victims become more difficult to identify in a world where we see how they are connected together. This may in fact be one reason Danbom is troubled by Nature's Metropolis, for in it I am not really inclined to point fingers at anyone. I describe a vast human cultural system transforming the natural landscapes of the midcontinent, a system in which, as Danbom notes, farmers participated as actively as merchants or factory-owners. No one person can be blamed or praised for the extraordinary changes that occurred, some of which we may see as good, some of which we may see as bad, and most of which we will probably see as being a little bit of both.

I see no pure heroes or pure villains in the stories I tell, so I have trouble recognizing a description of Nature's Metropolis as "a book about evil unleavened by good, about sin without redemption, about guilt and about complicity." Rather, I hope it is about moral ambiguity. Americans at the end of the nine- 
teenth century lamented the passing of the frontier even as they celebrated the triumphant progress that was transforming their nation. Surely we can feel similarly ambivalent emotions as we contemplate the very real achievements of American farmers even as we recognize the ecological price they sometimes paid for their homes.

I don't want to leave the mistaken impression that I think David Danbom has completely misunderstood Nature's Metropolis. If we disagree at all, it is only about whether environmental and agricultural historians have intrinsically opposing viewpoints. I do not believe they do. I am particularly grateful to Danbom for pointing out that Nature's Metropolis implicitly engages recent debates among rural and agricultural historians about whether early American farmers were precommercial or precapitalist in their economic behavior and cultural values. Although I admire the work that scholars like Steven Hahn, Jonathan Prude, Christopher Clark, and John Mack Faragher have been doing, I differ from them in believing that frontier farmers were at least somewhat oriented toward commercial exchange and market production almost from the beginning.

This argument was central to the way Changes in the Land contrasted Indian and colonial land-use practices in New England. Surprisingly, to my knowledge no scholar has explicitly commented on how that book's systemic analysis of colonial ecological change-again, with no pure heroes or villains-relates to the historiographical debate about precommercial rural economies. This is another of those situations where I see shades of gray rather than stark blacks and whites. To my eye, colonial farmers look much more market-oriented in their attitudes toward real estate and crop production than did precolonial Indians. On the other hand, colonial farmers sent to market a much smaller fraction of their annual produce than did the farm families who settled Chicago's hinterland in the nineteenth century. My conclusion is not that one group was capitalist and the other not, but that commercial exchange and capitalist production have undergone an extraordinarily complex evolution, in agriculture as elsewhere, over the past several centuries. Our job as historians would be easier and probably less contentious if we conceived of the transition to capitalism 
as a complex, multistaged process rather than as a simple dichotomous either-or transformation.

Philip V. Scarpino is the only scholar among these four critics who identifies himself as an environmental historian, and as one might expect, he is much more sympathetic to the book's general theoretical stance than David Danbom is. Scarpino quotes with approval the passage from Aldo Leopold's A Sand County Almanac, which calls for "an ecological interpretation of history." His description of Chicago's hinterland does an excellent job of summarizing my own version of what such an interpretation looks like: "an interconnected and interdependent system that integrates nature's economy and the human economy into a vast 'second nature' that owes its geography to the flow of capital drawn on 'first nature's' account." An integrated system of ecological and economic relationships, rather than a fallen land of evil and sin, is the way an environmental historian is likely to see the world of Nature's Metropolis.

Scarpino joins Malcolm Rohrbough in noting that the book tells only the middle of its story. While Rohrbough pointed us further back toward earlier frontier cities and hinterlands in the trans-Appalachian West, Scarpino points us forward, toward the emerging conservation consciousness that the citizens of Chicago began to embrace toward the end of the nineteenth century. As resources became scarcer and as the environmental consequences of frontier settlement became more palpable, groups such as the Izaak Walton League began to try to mitigate the most serious ecological effects of progress. Scarpino has told this story well in his own book, Great River, which picks up at almost exactly the point where Nature's Metropolis leaves off. ${ }^{34}$ I would commend it to any reader who wishes to trace the next phase of this story.

I also wish to endorse Scarpino's plea for scholars to make their academic research more accessible to the broader public. I did in fact try to write Nature's Metropolis for an audience beyond the academy, but the technical arguments that make it more rigorous than Changes in the Land also make it a more dif-

34. Philip V. Scarpino, Great River: An Environmental History of the Upper Mississippi, 1890-1950 (Columbia, MO, 1985). 
ficult book to read. Scarpino calls on historians to repackage books like these for different media, and notes the effectiveness of museum exhibits in reaching people who might not otherwise encounter such material. Film and television documentaries also seem well suited to the task of making this kind of history more accessible, and I emphatically agree with Scarpino that more scholars should be trying to work in such media.

In closing, I want to repeat my thanks to Marvin Bergman for making this symposium possible, and to these four commentators for their very thoughtful criticisms. I am grateful to all, and hope that as a result of this discussion fewer people will think of Nature's Metropolis as a book mainly about Chicago. For myself, I think of it as a book mainly about lowa (and my home state of Wisconsin as well) that nonetheless pays a lot of attention to the extraordinary city at the southwestern corner of Lake Michigan-because the history of nineteenth-century Iowa and Wisconsin is the history of Chicago as well. 
Copyright of Annals of Iowa is the property of State of Iowa, by \& through the State Historical Society of Iowa and its content may not be copied or emailed to multiple sites or posted to a listserv without the copyright holder's express written permission. However, users may print, download, or email articles for individual use. 